\title{
A man with a mission
}

\section{惑星科学界の敏腕男}

Nature Vol.436 (618-619) / 4 August 2005

2015 年、冥王星に初めての探査機が到着する。「ニューホライズン」と名づけられたこの無人探査機計画は、惑星科 学者Alan Stern が大切に育ててきたものだ。Amanda Haag が取材した。

宇宙探査の世界では、苦労が報われるのが 遠い先の話であるのはよくあることだ。探 査機が打ち上げられてから科学的な成果の 発表につながるまで、10 年やそれ以上かか る場合もある。

AlanStern は、米航空宇宙局 (NASA) か 2006 年 1 月に打ち上げる予定の、冥王星と さらにその向こうの冷たい世界を探索すると いうニューホライズン計画のPI (主任研究者) である。彼は、上層大気での実験を行うため にジェット戦闘機で飛んだことや、彗星を訪 れる探査機を送りだしたこともあり、スペー スシャトルのミッションスペシャリストの資 格ももつ。と同時に、惑星科学の世界におけ る最精鋭で創造的なグループの 1 つである、 サウスウエスト研究所ボールダー支所（コロ ラド州）の研究グループを率いている。

47 歳の「宇宙中毒患者」であるStern の さまざまな業績のなかでも、冥王星探査は 最もよく知られたものになりそうだ。彼は、 この探査計画の必要性を、何年もの間ほと んどたったひとりで訴えてきた。彼がニュー ホライズンという形で計画を復活させるま での 12 年間、さまざまな冥王星探査機に予 算がついてはキャンセルされてきた。しか し、計画が復活してもまだ一息つくわけには いかなかった。ニューホライズンの実現は予 算しだいということになり、その予算獲得を めぐる闘いがさらに 2 年間続いたのである。 彼は半ば冗談で「この探査機は、太陽系を 横切るよりも、ワシントン環状道路を抜け出 るのに長い時間かかったよ」と話す。

子供時代のStern は、すぐに宇宙の魅力 にとりつかれた。1960 年代のたいていの子 どもたちがそうだったように、アポロ宇宙 計画にとても感動して育ったという。10 代
になると、彼は典型的な「宇宙おたく」になっ た。「それもかなり筋金入りのね」と冗談め かして振り返る。しかし、宇宙に魅了されて も、それが学校の成績に常に結びつくわけ ではなかった。テキサス州ダラスの厳しい 私立の男子高校を卒業し、テキサス大学オー スティン校で自由を楽しんだ。あまりに楽 しみすぎてほとんど退学処分になりそうに なり、自ら大学を退学した。そして半年の あいだ、港湾労働者として働く日々が過ぎ、 もう一度大学に挑戦することを決意した。

\section{再び大学へ}

Stern はトレードマークの熱心さでもって、 すぐに2つの学士と2つの修士の学位を取つ た。航空宇宙産業で 2 年間を過ごし、やが て学究的生活を職業の選択肢と考えるよう になった。そして1983年、コロラド大学ボー ルダー校の大気宇宙物理学研究所で仕事を 得た。まもなく、ハレー彗星を調べる目的で、 スペースシャトル「チャレンジャー号」に 搭載される、紫外線分光計 1 対を作る作業 を手伝うのがメインの仕事の 1 つとなった。 そしてその計画が進むにつれ、工学よりも 純粋科学の方に引きつけられるようになる。 「宇宙科学者になりたいと決心した」。ボー ルダーの中心街にあるオフィスで、とがっ たフラットアイアン山脈の美しい眺めを見 ながら、私は彼のそんな経歴に耳を傾けた。

しかし、ハレー彗星観測装置を乗せたチャ レンジャー号は 1986 年 1 月 28 日の打ち 上げ直後に爆発し、米国の宇宙計画はストッ プする。観測計画への彼の期待もくじかれ た。「私たちがしていたすべての仕事が、数 年間延期されるように思えた」。1 か月足ら ずのち、彼は大学院に戻ることを決めた。

\section{米国中から研究者を集める}

わずか 3 年でコロラド大学で博士号を取 得したStern は、その後 2 年足らずで、サ ウスウエスト研究所のテキサス州サンアン トニオにある本部に、惑星科学グループを 立ち上げるために雇われた。サンアントニ オのこの研究所は当時、強力な宇宙科学研 究グループを擁していることですでによく 知られていたが、惑星科学についてはまだ 無名だった。「どの研究機関に行ったとして も、自分の研究が優先されるようになるま で普通 10 年や 15 年、列をなして待つこと になるものだ。しかし、サウスウエスト研 究所の惑星科学部門にはその順番待ちの列 がなかった。成功するかしないかは自分し だい。わくわくすると同時に恐ろしい気も した」と彼は話す。

Stern はたくさんの研究奨励金を獲得し、 提案した宇宙探査計画観測装置案も多数が 採用された。しかし、サンアントニオには ある重要な要素が欠けていることに気づい た。研究が活発な大学と、惑星科学専門家 のコミュニティだ。当時、サンアントニオ に来ることに関心をもつ新人研究者はほと んどいなかった。1993 年にあったあるパー ティーで、Stern は 3 人の優秀な惑星科学 者と隣り合わせた。彼らは、サウスウエス 卜研究所からのオファーを断っていた。ワ インが豊富に振る舞われはじめると、彼ら はStern にこう話したという。「もし、あな たがボールダーか、あるいはどこか別の研 究の活発な大学があるような場所で研究を していたら、私たちはサウスウエスト研究 所に加わっていたと思うよ」Stern は「そ れはまるで神のお告げのようなものだった」 と振り返る。 
このときStern は、自分が心に描く、時 代を画するような惑星研究グループを作る ために大きく踏みださなければならないこ とを確信した。彼と、彼の上司である磁気 圏科学者 James Burch は、サウスウエス 卜研究所の Martin Goland 所長のところへ 直行した。Goland は、最終的にSternの 申し入れを受け入れるまでに 2 回、彼を才 フィスから追い返している。それから 11 年。 Stern が開設したサウスウエスト研究所ボー ルダー支所は、科学者 2 人からはじまって 今では 40 人をこえる規模にまで成長し、惑 星科学と太陽物理学に関する広範囲の研究 分野をカバーしている。

この研究部門を拡大するため、Stern は米 国中からえり抜きの科学者を引き入れた。彼 は、小惑星の専門家 Dan Durda を、ジェッ 卜戦闘機を使って空から天体観測を行うこ とを約束して誘いこんだ。Stern とDurda はその後、観測に有利な高度 1 万 $7000 \times ー$ トルから太陽近くの小惑星を研究するため の高性能望遠鏡を完成させた。サウスウエ スト研究所ボールダー支所に加わって以来、 Durda の研究は「できると考えたこともな かった」領域にまで広がったという。余暇に ほら穴のダイビングを楽しむ彼は今、木星 の衛星エウロパの水の下を調べる技術をサ ウスウエスト研究所の協力で開発している。 彼はその実地訓練のため、観測ロボットをメ キシコの深いドリーネ（石两岩地方に生ずる すりばち状のくぼ地）の中に下ろしている。

Stern は、この研究部門を彼独特の計算 に基づいてデザインした。彼の 1 つの夢は、 学際的な研究部門を作り、大学に伝統的に 根づく問題にとらわれないようにすること だった。研究資金には、制約の少ない研究 奨励金をあてた。最も重要なのは、研究所 内で縄張り争いがないよう計画されている ことだ。どの研究グループも、常に同じ場 所にかたまって研究することは許されてい ない。「ここでは、席を求めてみんな常に動 きまわり、互いが研究している横を通りす ぎることになる」。その結果、「ここは本当に 知的なエネルギーに満ちている場所で、研 究所のホールを歩けば、自分でも気がつか ないうちにおもしろいプロジェクトに引き こまれてしまうことになる」と同支所で地球 型惑星の進化を研究している科学者 David Grinspoon はいう。

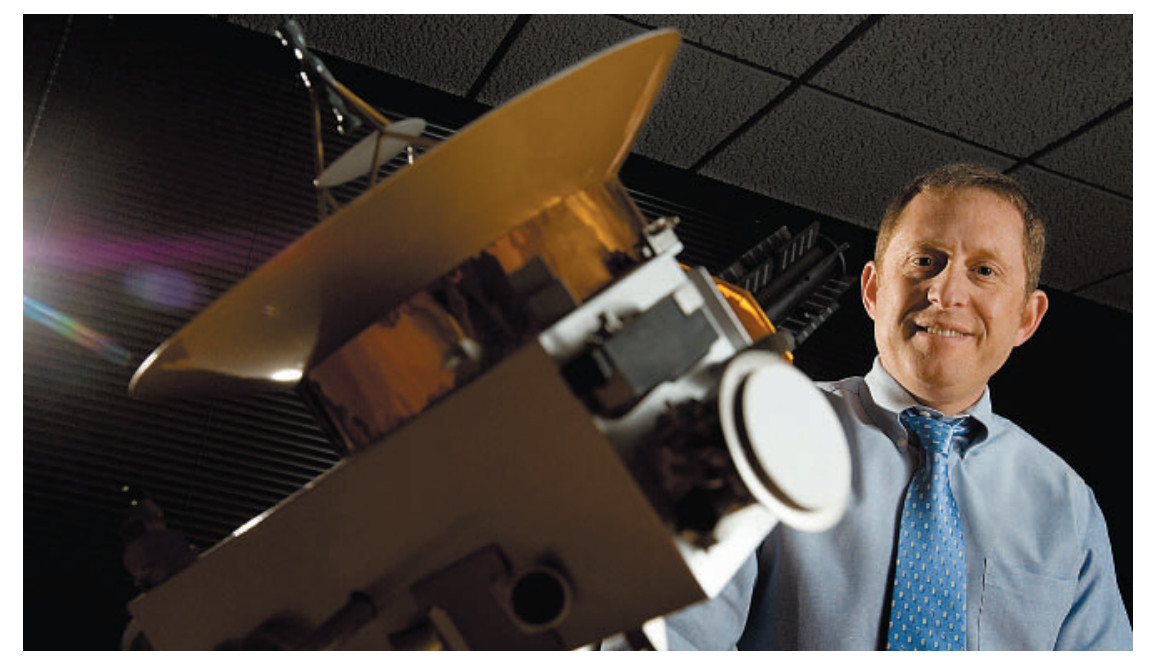

\section{冥王星で見つけるもの}

制約の少ない研究奨励金ベースの仕事は、 一時的なポストとみなされることが多い。 しかし、サウスウエスト研究所ボールダー 支所の研究者の多くはライバルの研究所か らポストの申し出を受けたにもかかわらず、 ひとりもよそに移っていくことはなかった。 コロラド大学の天体物理学者でStern の博 士号アドバイザーのひとりだった Michael Shull は「この研究所の繁栄は、ありうるだ ろうと思われていたのをはるかにこえたサ クセスストーリーだ。よいう。

Stern は、研究部門をさらによいものにし ようとエ夫をこらす以外にも、冥王星の先 の水で覆われた世界にある、彗星などの研 究で忙しい。太陽からおよそ 50 億〜80 億 キロにあるこの遠い領域はカイパーベルト とよばれ、冥王星やその衛星カロンのほか にも、軌道を回る冷たい天体がたくさんあ ることがわかった。「ここは太陽系の屋根裏 部屋のようなもので、あらゆる種類のもの が詰めこまれている。たとえば、小さなも のから並みの大きさのものまで、20 年前に は予想もされていなかった、ばく大な数の 『惑星』がある」と彼は話す。

Sternは、2008 年末か 2009 年初めに 月を訪れる、NASA の「ルナ・リコネサンス オービター」(月探査衛星、LRO) の準備に も取り組んでいる。彼はこの探査機の紫外 線分光計の PI である。また、2014 年初め に彗星に到着する、欧州宇宙機関（ESA）の 彗星探査機「口ゼッ夕」の紫外線分光計の PI でもある。そしてすべてがうまくいけば、 2015 年にニューホライズンが冥王星とカロ
ンの上空を飛ぶことになる。「2010 年代は、 私にとってとてもすばらしい 10 年になるは ずだ」と彼は話す。

研究者として非常に精力的に働きながら も、Stern は夫として、3人の子どもの父親 としての務めも果たしている。私が彼と会っ た最初の日、一番上の娘 Sarah が初めての 車を買うのについていくため、急いで外に 出るところだった。週末には 3 人の子ども とそれぞれの時間を過ごす。

Stern は、冥王星にいったい何を期待し ているのだろう。冥王星探査計画の初期の 検討が具体化していた 1993 年の会議で、 科学者たちは冥王星がどんな謎を秘めてい るかについて自分の予測を書き、封筒に入 れて封をした。これは探査機が冥王星にた どり着いたときに開けられる。Sternは「自 分の予測の内容を話してはいけないことに なっているのだが、あなたには話そう」と いってくれた。

私はどきどきしながら身を乗りだした。 「予測は 2 語ですべて。『何か驚くべきもの (something wonderful)』、と書いた。太 陽系のなかで同じものは 1 つとしてない。 だから私たちはいつも、何かきわめて驚く ベきものを知ることになるんだ」。

AmandaHaag は米国コロラド州ボールダーの フリーランスライター。 